\title{
Efficacy of Euphorbia helioscopia in context to a possible connection between antioxidant and antidiabetic activities: a comparative study of different extracts
}

Imtiaz Mustafa', Muhammad Naeem Faisal'², Ghulam Hussain'1, Humaira Muzaffar ${ }^{1}$, Muhammad Imran³, Muhammad Umar ljaz ${ }^{4}$, Muhammad Umar Sohail ${ }^{5}$, Arslan Iftikhar ${ }^{1}$, Arslan Shaukat ${ }^{1}$ and Haseeb Anwar ${ }^{1 *}$ (D)

\begin{abstract}
Background: Euphorbia helioscopia, conventionally known as sun spurge, has been used as a traditional medicine to treat different diseases owing to its reported antitumor, antiviral and antioxidant activities.

Methods: The current research was formulated to assess the in-vitro antioxidant and antidiabetic ability of Euphorbia helioscopia subsequent to the phytochemical analysis of its various extracts. For this purpose, methanol, ethanol and aqueous extracts were prepared using the whole dried plant. Phytochemical analysis of the extracts was done to evaluate the total flavonoid components (TFC) and total phenolic components (TPC) in the extracts. A total of seven phenolic and three flavonoid contents were documented and quantified using HPLC. Antioxidant values were found by DPPH assay, FRAP and ABTS assays. The antidiabetic potential of the extracts was evaluated by measuring the inhibition ability of the activity of enzymes a amylase and a glucosidase.

Results: After analyzing statistically, the results showed that methanolic extract possesses the highest TFC and TPC values while aqueous extract encompassed the lowest level of these contents. Invitro results showed that methanolic extract of the Euphorbia helioscopia has the maximum antioxidant capability since it showed the highest scavenging ability towards the $\mathrm{DPPH}^{\bullet}\left(\mathrm{IC}_{50}\right.$ value $\left.=0.06 \pm 0.02 \mathrm{mg} / \mathrm{ml}\right)$, FRAP $\left(758.9 \pm 25.1 \mu \mathrm{MFe}^{+2} / \mathrm{g}\right)$, and ABTS $(689 \pm 25.94$ $\mu \mathrm{MTEq} / \mathrm{g})$ due to the presence of high TPC $(24.77 \pm 0.35 \mathrm{mgGAEq} / \mathrm{g})$ and TFC $(17.95 \pm 0.32 \mathrm{mgQEq} / \mathrm{g})$ values. Antidiabetic activity in terms of inhibition potential of a amylase and a glucosidase activity was also observed maximum in methanolic extract having lowest $I C_{50}$ value $(0.4 \pm 0.01 \mathrm{mg} / \mathrm{ml}$ and $0.45 \pm 0.01 \mathrm{mg} / \mathrm{ml}$ respectively) and minimum in the aqueous extract $\left(I_{50}\right.$ value $=0.57 \pm 0.02 \mathrm{mg} / \mathrm{ml}$ and $0.76 \pm 0.1 \mathrm{mg} / \mathrm{ml}$ respectively).

Conclusion: The experiment outcomes have shown that Euphorbia helioscopia extracts used in the current study contain antioxidant and antidiabetic activities; however, it is highest in its methanolic extract. The presence of the same trend towards the highest antidiabetic activity of the methanolic extract in terms of maximum inhibiting activity of a amylase and a glucosidase enzymes suggests a close association of TFC and TPC in minimizing diabetes.
\end{abstract}

Keywords: Euphorbia helioscopia, Methanolic extract, Antioxidant, Antidiabetic

\footnotetext{
* Correspondence: drhaseebanwar@gcuf.edu.pk

'Department of Physiology, Faculty of Life Sciences, Government College University, Faisalabad, Pakistan

Full list of author information is available at the end of the article
}

(c) The Author(s). 2021 Open Access This article is licensed under a Creative Commons Attribution 4.0 International License, which permits use, sharing, adaptation, distribution and reproduction in any medium or format, as long as you give appropriate credit to the original author(s) and the source, provide a link to the Creative Commons licence, and indicate if changes were made. The images or other third party material in this article are included in the article's Creative Commons licence, unless indicated otherwise in a credit line to the material. If material is not included in the article's Creative Commons licence and your intended use is not permitted by statutory regulation or exceeds the permitted use, you will need to obtain permission directly from the copyright holder. To view a copy of this licence, visit http://creativecommons.org/licenses/by/4.0/. The Creative Commons Public Domain Dedication waiver (http://creativecommons.org/publicdomain/zero/1.0/) applies to the data made available in this article, unless otherwise stated in a credit line to the data. 


\section{Background}

In recent decades, various natural plant extracts have exhibited significant antioxidant activity [1, 2]. These extracts encompass significant amounts of different bioactive molecules used in various pharmaceutical industry products [3, 4]. Particularly antioxidant molecules have upraised much attention because these secondary metabolites possess numerous pharmacological possessions [5]. One or more active ingredients from plants have been found in about $25 \%$ of all prescriptions [6]. Disproportionate reactive oxygen species that are derived from oxygen and nitrogen are the chief cause of the oxidative injury to tissues and organs [7, 8]. Oxidative damage has been reflected as a pathological process that playss a role to initiate and develop many diseases [9]. Oxidative stress can be induced by various factors including drugs, smoking, alcohol and environmental pollutants that may lead to hyperglycemia [10]. Various transcription factors that control the cellular responses to reactive oxygen species (ROS) can be triggered by ROS [11]. Increased ROS level is one of the important aspects in the progression of type 2 diabetes mellitus $[12,13]$. In case of diabetes, ROS formation may be due to the oxidation of glucose, nonenzymatic glycation of proteins, and enhanced peroxidation of lipids that causes harm to the cells and enzymes leading to insulin resistance [14].

Euphorbiaceae family includes several medicinal plants across the world that contain a wide range of various therapeutic effects proposing the extent of chemical nature of extracts of plants of this group. Euphorbia helioscopia is a remarkable herbaceous annual medicinal plant of spurge family Euphorbiaceae indigenous to Asia, Europe and northern Africa. It contains almost 24 secondary metabolites, including euphornin, euphornins $(\mathrm{B}, \mathrm{C})$, euphoheliosnoid $\mathrm{D}$, hemistepsin, helioscopinolide $(\mathrm{B}, \mathrm{C})$, licochalcone $(\mathrm{A}, \mathrm{B})$ echinatia, guaiane lactone, galabrone and 4', 5,7-trihdroxyflavanone [15]. Because of the presence of a number of secondary metabolites, this plant has the diverse pharmacological effects including anti-inflammatory, vasodepressor activity, antimicrobial activity, antitumor, antioxidant and wound healing properties [16-20]. The plant has been used conventionally to cure different pathological conditions including skin diseases, warts, intestinal parasites, migraine and gonorrhea [21]. Leaves and stems of the plants are traditionally used as vermifuge and its seeds are used in cholera and constipation. Present research is designed to evaluate and compare the antioxidant and antidiabetic efficacy of methanolic, ethanolic and aqueous extracts of the Euphorbia helioscopia.

\section{Methods}

\section{Procurement of plants}

The plant Euphorbia helioscopia was locally collected from the fields of Ayub Agriculture Research Institute Faisalabad, Pakistan. The plant was identified by the expert Botanist with a voucher specimen numbered 247bot-2020, and kept in the herbarium of the Department of Botany, Government College University Faisalabad, Pakistan.

\section{Extract preparation}

After washing with distilled water, the plant was shade dried and grinded into a fine powder and $50 \mathrm{~g}$ of the powder was soaked for $72 \mathrm{~h}$ in $250 \mathrm{ml}$ each of ethanol, methanol and distilled water with periodically stirring and mixing. The solutions were subsequently sieved through Whatman ${ }^{\circledR}$ filter paper. The extracts after filtration were evaporated and concentrated using a rotary evaporator (SCI100-Pro; SCILOGEX, USA) at $40^{\circ} \mathrm{C}$ and transferred into labeled petri dishes and kept in incubator at $40{ }^{\circ} \mathrm{C}$ until dried properly. The percentage yield was calculated as 15.7, 11.2 and $13.9 \%$ for methanolic, ethanolic and aqueous extracts of the plant respectively. The extracts were stored at $4{ }^{\circ} \mathrm{C}$ till further analysis.

\section{Qualitative phytochemical analysis}

Phytochemical analysis of methanolic, ethanolic, and water extracts of the plant was carried out qualitatively using standard methods as described by Singh and Bag [22] to verify the presence or absence of potentially active phytochemicals.

\section{Quantitative phytochemical estimation Total phenolic constituents ( $\mathrm{mg}$ of gallic acid equivalent/g dry weight of plant)}

A volume of $30 \mu \mathrm{l}$ plant extracts $(1 \mathrm{mg} / \mathrm{ml})$ was diluted with $30 \mu \mathrm{l}$ of folin_ciocalteu reagent and $2.5 \% \mathrm{Na}_{2} \mathrm{CO}_{3}$ $(600 \mu \mathrm{l})$. After keeping at room temperature for $60 \mathrm{~min}$, optical density was taken at $760 \mathrm{~nm}$ using a chemistry analyzer (Biolab-310). A gallic acid standard curve (0.789 to $200 \mu \mathrm{g} / \mathrm{ml}$ ) was used for TPC evaluation [23].

\section{Total flavonoid contents ( $m g$ of quercetin equivalent/g dry weight of plant)}

Flavonoid contents were identified by using quercetin as a standard (0 to $100 \mu \mathrm{g} / \mathrm{ml}$ ) following to the procedure previously adopted by Kumar et al. [23]. In a nutshell, each plant extract $(100 \mu \mathrm{l})$ was mixed with distilled water $(1 \mathrm{ml})$. After room temperature incubation for $5 \mathrm{~min}$, $\mathrm{AlCl}_{3}(125 \mu \mathrm{l})$ and $5 \% \mathrm{NaNO}_{2}(75 \mu \mathrm{l})$ were mixed and kept again at room temperature for $6 \mathrm{~min}$. Then, $1 \mathrm{M}$ $\mathrm{NaOH}(125 \mu \mathrm{l})$ and distilled water $(2.5 \mathrm{ml})$ were added and absorbance was taken by using a chemistry analyzer (Biolab-310) at $540 \mathrm{~nm}$.

\section{Identification and quantification of phenolic constituents}

A volume of $10 \mu \mathrm{l}$ of plant extracts $(0.1 \mathrm{~g} / \mathrm{ml}$ in methanol) was injected in the HPLC system (HP 1050 gradient) with a detector (SPD-10AV) for estimation of 
phenolic profile. Stationary phase of Shim-Pack CLCODS C-18 column $(5 \mu \mathrm{m}, 5 \mathrm{~cm} \times 4.5 \mathrm{~mm})$ Shimadzu, Japan $^{\bullet}$ was used. A mixture of distilled water and glacial acetic acid in a v/v ratio of 24:0.4:320:56, was used as mobile phase. Different phenolic contents were measured with a 10 min linear gradient at room temperature [24].

\section{In-vitro antioxidant evaluation FRAP assay ( $\mu$ mole $\left.\mathrm{Fe}^{2+} / g \mathrm{DW}\right)$}

The FRAP was evaluated by using the procedure adopted previously by Dudonne et al. [25]. An amount of $3.995 \mathrm{ml}$ of the final working solution [ten parts of $300 \mathrm{mM}$ acetate buffer, one part of $10 \mathrm{mM} \mathrm{2,4,6-tri} \mathrm{\{ 2-}$ pyridyl\}-s-triazine in $40 \mathrm{mM} \mathrm{HCL}$, one portion of 20 $\mathrm{mM}$ ferric Chloride] was diluted with $5 \mu \mathrm{l}$ of the sample solution. The optical density was measured at $593 \mathrm{~nm}$ to evaluate the reducing ability. Results were determined by the comparison of absorbance with the standard curve constructed from different concentrations (0 to 1000 $\mu$ Mole) of ferrous sulphate $\left(\mathrm{FeSO}_{4}\right)$ and expressed as $\mu$ mole $\mathrm{Fe}^{2+} / \mathrm{g}$ dry weight of the plant.

\section{ABTS assay (Trolox equivalent/g DW)}

The ABTS scavenging potential was measured by using the ABTS assay previously used by Dudonne et al. [25]. A working solution of ABTS was made by mixing $7 \mathrm{mM}$ of aqueous solution of ABTS and $2.5 \mathrm{mM}$ of potassium persulfate in a 1:1 ratio. This ABTS working solution was further mixed with methanol to obtain an absorbance of almost 0.7 at wavelength $734 \mathrm{~nm}$. After that, $5 \mu \mathrm{l}$ of each plant extract solution was diluted with ABTS solution $(3.995 \mathrm{ml})$. After keeping for $30 \mathrm{~min}$ at room temperature, optical density was taken at $734 \mathrm{~nm}$ and results were calculated by comparing the absorbances with a standard curve made from Trolox in various concentrations ( 0 to $800 \mu \mathrm{Mole})$. The final values were shown as mg Trolox equiv./g of dry weight of the plant.

\section{$D P P H^{\bullet}$ scavenging assay}

Sample solution $(5 \mu \mathrm{l})$ of different concentrations in methanol $(5,2.5,1.25,0.62$ and $3.12 \mathrm{mg} / \mathrm{ml})$ was mixed with $585 \mu \mathrm{LPPH} \mathrm{DP}^{\bullet}$ solution in methanol $(0.2 \%)$ and kept at room temperature for almost twenty minutes. Then optical density was measured at $515 \mathrm{~nm}$ by using a chemistry analyzer (Biolab-310). The scavenging ability in percentage was measured by using the following formula:

$$
\text { Scavenging }(\%)=100 \times \frac{A b s^{\mathrm{bl}}-A b s^{\mathrm{sp}}}{A b s^{\mathrm{bl}}}
$$

Where $\mathrm{Abs}^{\mathrm{bl}}$ is the optical density of the DPPH ${ }^{\bullet}$ blank solution and $\mathrm{Abs}^{\mathrm{sp}}$ is the optical density of the extracts.
A graph was plotted between percentage inhibition and extract concentration to calculate the concentration with $50 \%$ scavenging power $\left(\mathrm{IC}_{50}\right)[26]$.

\section{Antidiabetic potential Inhibition of a amylase activity}

It was evaluated by the methodology as described previously [27] with a few modifications. Five serial diluted concentrations $(0.312$ to $5 \mathrm{mg} / \mathrm{ml})$ of the plant extract $(500 \mu \mathrm{l})$ and $500 \mu \mathrm{l}$ of porcine pancreatic amylase solution $\left(0.5 \mathrm{mgml}^{-1}\right.$ in $0.02 \mathrm{M}$ PBS with $6.9 \mathrm{pH}$ having $0.006 \mathrm{M} \mathrm{NaCl}$ ) was poured and incubated for $10 \mathrm{~min}$ at room temperature. Then $0.5 \mathrm{ml}$ of $1 \%$ starch in $0.02 \mathrm{M}$ PBS with $6.9 \mathrm{pH}$ was mixed and kept at room temperature for $10 \mathrm{~min}$ and $1 \mathrm{ml}$ of DNSA color reagent was added. The solution was then retained in a boiling water bath for $10 \mathrm{~min}$ to stop the reaction and diluted with $10 \mathrm{ml} \mathrm{dH}_{2} \mathrm{O}$. At $540 \mathrm{~nm}$, absorbance was measured by using a chemistry analyzer (Biolab- $310^{\circ}$ ). Acarbose (Acr), a standard drug used to inhibit $\alpha$ amylase action, was also run in the same manner in different concentrations in place of the extracts. A blank solution was also run with $100 \%$ enzyme activity having no extract or the standard drug. The following formula was used to determine the percentage enzyme inhibition.

$$
\text { Inhibition }(\%)=100 \times \frac{\text { abs of blank }- \text { abs of sample/standard }}{\text { abs of blank }}
$$

The concentration of the extract or the standard was calculated, having $50 \%$ inhibition of the enzyme activity (IC50) by constructing a graph of various quantities of the extracts and acarbose against their percent inhibition.

\section{a glucosidase inhibitory activity}

A volume of $980 \mu \mathrm{l}$ of pNPG solution ( $290 \mathrm{mM} \beta$-D glucopyranoside in $20 \mathrm{mM}$ citrate buffer with $5.6 \mathrm{pH}$ ) was mixed with $200 \mu \mathrm{l}$ of five different concentrations of plant extracts and acarbose standard (5, 2.5, 1.25, 0.625, $0.312 \mathrm{mg} / \mathrm{ml}$ ). This mixture after $5 \mathrm{~min}$ incubation at $37^{\circ} \mathrm{C}$ was diluted with $20 \mu \mathrm{l}$ of $\alpha$ glucosidase solution (1 $\mathrm{U} / \mathrm{ml}$ ) and kept at $35^{\circ} \mathrm{C}$ for $40 \mathrm{~min}$. The reaction was stopped by the addition of $200 \mu \mathrm{L}$ of $6 \mathrm{~N} \mathrm{HCl}$, and optical density was measured at $405 \mathrm{~nm}$ by using chemistry analyzer (Biolab-310 $)$. A blank solution was also run in a similar manner without the extract sample or acarbose.

$$
\text { Percent Inhibition }=100 \times \frac{A b s^{\mathrm{bl}}-A b s^{\mathrm{sp}}}{A b s^{\mathrm{bl}}}
$$

Where $\mathrm{Abs}^{\mathrm{sp}}$ is the optical density of the sample and acarbose and $\mathrm{Abs}^{\mathrm{bl}}$ is the optical density of blank. All the samples and acarbose were run in triplicate and $\mathrm{IC}_{50}$ 
value was calculated by constructing a chart of different quantities of the extracts and acarbose against their percent inhibition [27].

\section{Statistical study}

All the measurements were calculated in triplicates and the data was analyzed for the mean \pm standard deviation by using GraphPad Prism-8 software. Correlations were calculated by means of bivariate linear correlations $(p<$ 0.05 and $p<0.01$ ), using Pearson's correlation coefficient (r) in Microsoft office Excel 2010.

\section{Results}

\section{Qualitative phytochemical analysis}

Qualitative analysis of all three extracts of the plant is expressed in the Table. 1. It indicates the presence of different phytochemicals including alkaloids, phenols, anthraquinones, flavonoids, reducing sugar, saponins, terpenoids, steroids and tannins in MthEh, EthEh and AqEh.

\section{Total flavonoid and phenolic contents}

Results indicated that both the TFC and TPC were significantly higher in MthEh $(17.95 \pm 0.32 \mathrm{mgQE} / \mathrm{g}$ and $24.77 \pm 0.35 \mathrm{mgGAE} / \mathrm{g}$ respectively) in comparison to EthEh $(11.27 \pm 0.38 \mathrm{mgQE} / \mathrm{g}$ and $13.58 \pm 0.43 \mathrm{mgGAE} / \mathrm{g}$ respectively) and AqEh $(3.25 \pm 0.95 \mathrm{mgQE} / \mathrm{g}$ and $4.63 \pm$ $0.69 \mathrm{mgGAE} / \mathrm{g}$ respectively). Figure $1 \mathrm{a} \& \mathrm{~b}$ exhibited that TPC and TFC in the Euphorbia helioscopia extracts were in the following sequence: MthEh > EthEh > AqEh.

\section{Identification and quantification of phenolic contents}

Overall, seven phenolic contents, including gallic acid, chlorogenic acid, hydroxy benzoic acid, caffeic acid, Pcumaric acid, vanillic acid, ferulic acid, and three flavonoid contents comprising catechin acid, quercetin and rutin were identified and quantified by HPLC. Phenolic

Table 1 Qualitative Analysis of Euphorbia helioscopia

\begin{tabular}{|c|c|c|c|c|}
\hline No & Phytochemicals & MthEh & EthEh & AqEh \\
\hline 1 & Alkaloids & ++ & +++ & ++ \\
\hline 2 & Phenols & +++ & ++ & + \\
\hline 3 & Anthraquinones & - & - & - \\
\hline 4 & Flavonoids & +++ & ++ & + \\
\hline 5 & Reducing sugar & + & ++ & - \\
\hline 6 & Saponins & + & + & - \\
\hline 7 & Terpenoids & - & + & + \\
\hline 8 & Steroids & + & + & - \\
\hline 9 & Tannins & ++ & ++ & + \\
\hline
\end{tabular}

acids found in ethanolic extract included gallic acid, chlorogenic acid, caffeic acid, P-cumaric acid and ferulic acid, while phenolic compounds found in methanolic extract included gallic acid, hydroxybenzoic acid, chlorogenic acid, caffeic acid and vanillic acid and those found in aqueous extract included gallic acid, hydroxybenzoic acid, chlorogenic acid and caffeic acid as presented in Table. 2. Fig. 4a, b \& c are showing the chromatograms of different extracts of Euphorbia helioscopia plant. Among the phenolic contents, chlorogenic acid was found maximum in MtEh $(2368.06 .41 \pm 81.84 \mathrm{mg} / \mathrm{g})$ and AqEh $(1072.95 \pm 41.25 \mathrm{mg} / \mathrm{g})$ while gallic acid was found maximum in EthEh $(829.41 \pm 52.31 \mathrm{mg} / \mathrm{g})$. Three flavonoid contents were quantified in all three extracts (catechin acid, quercetin and rutin), among which rutin was found in maximum quantity in all the three extracts with an order as MthEh $>$ EthEh $>$ AqEh (Table. 2).

\section{In vitro antioxidant evaluation \\ FRAP assay (FeSo4 ( $\mu$ moleFe $\left.{ }^{2+} / g D W\right)$ ) and ABTS assay ( $\mu$ MTrolox Equiv./g DW)}

Results of both FRAP and ABTS assay are expressed in Table. 3 that indicated that the MthEh possess the highest reducing potential of $\mathrm{Fe}^{3+}$ into $\mathrm{Fe}^{2+}(758.9 \mu$ mo$\left.\mathrm{leFe}^{2+} / \mathrm{g}\right)$ as compared to the EthEh $\left(457.85 \mu \mathrm{moleFe}^{2+} /\right.$ g) and AqEh $\left(303.49 \mu\right.$ moleFe $\left.{ }^{2+} / \mathrm{g}\right)$ presented in Table. 3 . The same trend was seen in terms of scavenging ABTS radical being maximum in MthEh (689 $\mu \mathrm{MTE} / \mathrm{g})$ followed by EthEh $(575.17 \mu \mathrm{MTE} / \mathrm{g})$ and AqEh (287.39 $\mu \mathrm{MTE} / \mathrm{g}$ ) shown in Table. 3.

\section{$D P P H^{\bullet}$ radical scavenging activity}

The results showed a concentration-dependent increase in $\mathrm{DPPH}^{\bullet}$ scavenging activity in all three extracts with maximum activity in the MthEh (Fig. 1a) with the lowest $\mathrm{IC}_{50}$ value $(0.6 \pm 0.02 \mathrm{mg} / \mathrm{ml})$ in comparison of EthEh $(1.6 \pm 0.2 \mathrm{mg} / \mathrm{ml})$ and AqEh $(2.8 \pm 0.3 \mathrm{mg} / \mathrm{ml})$ as presented in Fig. 1b.

\section{Antidiabetic potential Inhibition of a amylase activity}

The result showed that Euphorbia helioscopia extracts contained the appreciable amylase inhibition activity in a concentration-dependent way (Fig. 2a). Among all three extracts, MthEh showed the maximum aamylase inhibitory activity in terms of having the lowest $\mathrm{IC}_{50}$ value of $0.4 \pm 0.01 \mathrm{mg} / \mathrm{ml}$ which was slightly higher than the standard drug acarbose $(0.32 \pm 0.008 \mathrm{mg} / \mathrm{ml})$ and lower than that of AqEh $(0.57 \pm 0.02 \mathrm{mg} / \mathrm{ml})$ and EthEh $(0.43 \pm 0.01 \mathrm{mg} / \mathrm{ml})$ (Fig. 2b).

\section{Inhibition of a Glucosidase activity}

The potential of the extracts and acarbose to inhibit $\alpha$ glucosidase enzyme activity was also seen in a 


\section{A DPPH Radical scavenging activity}

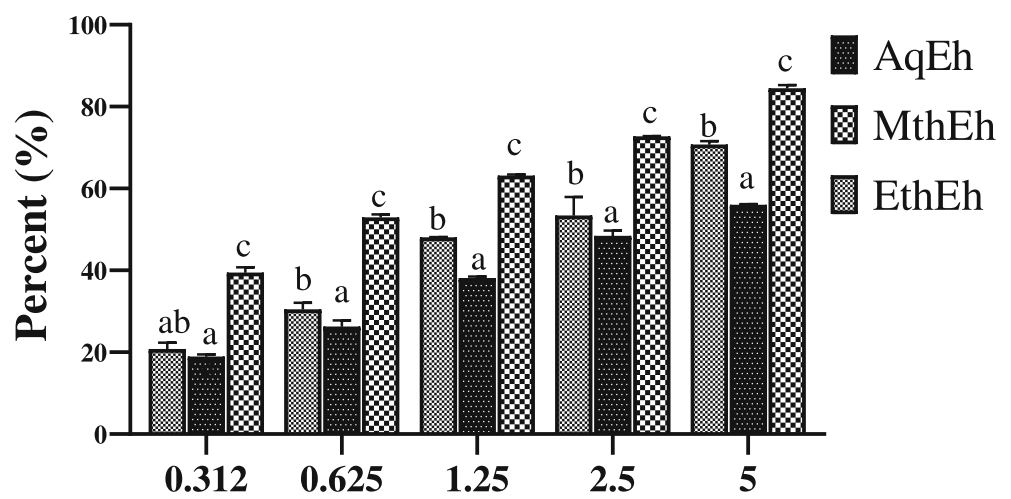

\section{B DPPH Radical scavenging activity}

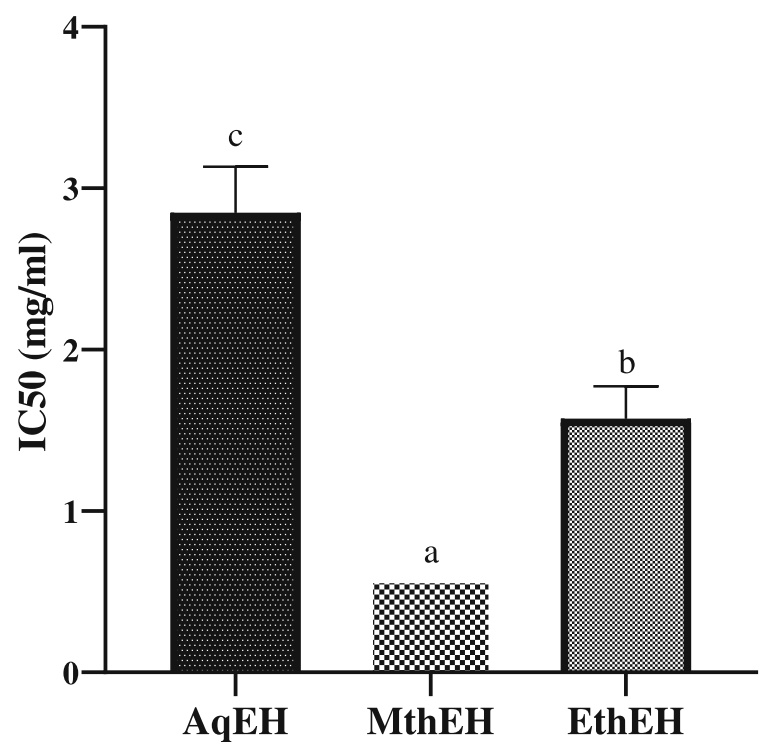

Fig. 1 a 2,2-diphenyl-1-picrylhydrazyl (DPPH ${ }^{\bullet}$ ) radical scavenging activity of five different concentrations of different extracts of Euphorbia helioscopia. b $\mathrm{IC}_{50}$ value of $\mathrm{DPPH} \boldsymbol{\bullet}^{\bullet}$ radical scavenging activity of different extracts of Euphorbia helioscopia. Results are Mean \pm Standard Deviation of three replicates of each group. Different lower case letters $\left({ }^{a}\right.$ to $\left.{ }^{9}\right)$ above the bars indicate a significant difference between groups $(P \leq 0.05)$. MthEh: methanolic extract of Euphorbia helioscopia; EthEh: Ethanolic extract of Euphorbia helioscopia; AqEh: Aqueous extract of Euphorbia helioscopia

concentration-dependent increase (Fig. 3a). The aqueous extract showed the highest $\mathrm{IC}_{50}$ value, which means that it has the lowest $\alpha$ glucosidase inhibitory activity in increasing order as AqEh $<$ EthEh $<$ MthEh $<$ Acr (Fig. 3b).

\section{Correlation among phytochemicals (TFC and TPC) and antioxidant potential}

Table. 4 indicates a positive correlation of about $99 \%$ among TPC and FRAP ( $r=0.993)$ and about $91 \%$ positive correlation among TPC and ABTS scavenging action ( $r=$ 0.953). Moreover, a strong negative correlation of about 98\% was seen among $\mathrm{TPC}$ and $\mathrm{IC}_{50}$ concentration of $\mathrm{DPPH}^{\bullet}$ radical scavenging action and TPC $(\mathrm{r}=-0.989)$, which indicates that the increase in TPC will minimize the quantity of the extract required to scavenge $50 \%$ of the $\mathrm{DPPH}^{\bullet}$. Correlation between TFC and antioxidant activity was also in the same manner (Table. 4).

\section{Correlation of phytochemicals (TFC and TPC) and antioxidants with antidiabetic activity}

A strong negative correlation was seen among TPC and $\mathrm{IC}_{50}$ values of $\alpha$ amylase inhibitory activity $(\mathrm{r}=-0.998)$. The correlation of TFC with $\mathrm{IC}_{50}$ of $\alpha$ amylase enzyme inhibition ability $(r=-0.999)$ also suggests an increase in TFC will increase the $\alpha$ amylase inhibitory activity (Table. 4). Correlation coefficients for the correlation of 
Table 2 HPLC Analysis of Different Extracts of Euphorbia helioscopia for Total Phenolic and Flavonoid Contents

\begin{tabular}{|c|c|c|c|}
\hline Compound Name & MthEh (mg/g) & EthEh $(\mathrm{mg} / \mathrm{g})$ & AqEh $(\mathrm{mg} / \mathrm{g})$ \\
\hline \multicolumn{4}{|l|}{ Phenolic Contents } \\
\hline Gallic Acid & $608.62 \pm 49.23^{b}$ & $829.41 \pm 52.31^{a}$ & $297.21 \pm 21.87^{c}$ \\
\hline HydroxyBenzoic Acid & N.D & $29.98 \pm 0.91^{\mathrm{a}}$ & $9.43 \pm 0.43^{b}$ \\
\hline Chlorogenic acid & $2368.06 \pm 81.84^{a}$ & $765.64 \pm 21.02^{c}$ & $1072.95 \pm 41.25^{b}$ \\
\hline Caffic acid & $42.69 \pm 1.21^{a}$ & $13.53 \pm 0.82^{b}$ & $13.53 \pm 0.61^{b}$ \\
\hline Vanlic acid & N.D & $17.40 \pm 0.51$ & N.D \\
\hline P-cumaric acid & $133.15 \pm 7.05$ & N.D & N.D \\
\hline Ferulic acid & $2.04 \pm 0.27$ & N.D & N.D \\
\hline \multicolumn{4}{|l|}{ Flavonoid Contents } \\
\hline Catechin acid & $814.87 \pm 102.7^{\mathrm{a}}$ & $774.7 \pm 62.31^{b}$ & $386.33 \pm 24.44^{c}$ \\
\hline Quercetin & $531.94 \pm 31.39^{a}$ & $226.94 \pm 9.81^{b}$ & $92.1 \pm 7.91^{c}$ \\
\hline Rutin & $2149.39 \pm 119.28^{a}$ & $1774.60 \pm 94.83^{b}$ & $741.11 \pm 37.21^{c}$ \\
\hline
\end{tabular}

$\mathrm{IC}_{50}$ values of $\alpha$ amylase enzyme inhibition activity with $\mathrm{IC}_{50}$ of $\mathrm{DPPH}^{\bullet}$ radical scavenging activity also show strong positive correlation $\mathrm{r}$ values are given in the Table. 4. A strong negative correlation of about $98 \%$ was seen among FRAP and $\mathrm{IC}_{50}$ of $\alpha$ amylase enzyme inhibition action. Moreover, the correlation among ABTS and $\mathrm{IC}_{50}$ of $\alpha$ amylase enzyme inhibition ability was found almost $99 \%(r=0.9916)$. Whereas $r$ value for the $\mathrm{IC}_{50}$ values of $\mathrm{DPPH}^{\bullet}$ with $\alpha$ amylase inhibitory activity was found 0.9996 .

The correlation of TFC and TPC with $\mathrm{IC}_{50}$ of $\alpha$ glucosidase enzyme inhibition action was found as $\mathrm{r}=-0.904$ and $\mathrm{r}=-0.848$, respectively. A similar correlation was seen among FRAP and $\mathrm{IC}_{50}$ value of $\alpha$ glucosidase inhibitory activity $(\mathrm{r}=-0.778)$, whereas $\mathrm{ABTS}$ and $\mathrm{IC}_{50}$ of $\alpha$ glucosidase enzyme inhibition activity was found negatively correlated with each other as $\mathrm{r}=-0.969$. The correlation of the $\mathrm{IC}_{50}$ value of $\mathrm{DPPH}^{\bullet}$ radical scavenging

Table 3 Total phenolic content, total flavonoid content, Ferric reducing antioxidant potential (FRAP), and Trolox equivalent antioxidant capacity (TEAC; ABTS Assay) of different extracts of Euphorbia helioscopia

\begin{tabular}{llll}
\hline & MthEh & EthEh & AqEh \\
\hline TPC $(\mathrm{mg} \mathrm{GAEq} / \mathrm{g})$ & $24.77^{\mathrm{c}} \pm 0.35$ & $13.58^{\mathrm{b}} \pm 0.43$ & $4.63^{\mathrm{a}} \pm 0.69$ \\
TFC $(\mathrm{mgQEq} / \mathrm{g})$ & $17.95^{\mathrm{c}} \pm 0.32$ & $11.27^{\mathrm{b}} \pm 0.38$ & $3.25^{\mathrm{a}} \pm 0.93$ \\
FRAP $\left(\mu \mathrm{MFe}^{+2} / \mathrm{g}\right)$ & $758.90^{\mathrm{c}} \pm 25.21$ & $457.85^{\mathrm{b}} \pm 13.15$ & $303.49^{\mathrm{a}} \pm 4.45$ \\
TEAC $(\mu \mathrm{MTEq} / \mathrm{g})$ & $689.00^{\mathrm{c}} \pm 25.94$ & $575.17^{\mathrm{b}} \pm 7.52$ & $287.39^{\mathrm{a}} \pm 13.90$ \\
\hline
\end{tabular}

Results are expressed as Means \pm SD (standard deviation). Values that do not share a superscript letter (a to $c$ ) in the same row are significantly different $(p \leq 0.5)$

MthEh Methanolic extract of Euphorbia helioscopia, EthEh Ethanolic extract of Euphorbia helioscopia, AqEh Aqueous extract of Euphorbia helioscopia activity with $\mathrm{IC}_{50}$ value of alpha glucosidase inhibitory activities was seen positive $(r=0.917)$ (Table. 4$)$.

\section{Discussion}

Medicinal plants possess huge quantities of antioxidant agents that play a significant role in the adsorption and neutralization of free radicals. These phytochemicals produce noteworthy antioxidant capacities in the plants that ultimately play a pivotal role in curing several human diseases [4]. Outcomes of the current study have shown that MthEh possessed the highest phenolic contents $24.77 \pm 0.35 \mathrm{mgGAE} / \mathrm{gDW}$ as compared to the EthEh $13.58 \pm 0.43 \mathrm{mgGAE} / \mathrm{gDW}$ and AqEh $4.63 \pm 0.69$ mgGAE/gDW extract. Similarly, the TFC were seen in high concentrations in MthEh $17.95 \pm 0.32 \mathrm{mgQE} / \mathrm{g}$ in contrast to the EthEh $11.27 \pm 0.38 \mathrm{mgQE} / \mathrm{g}$ and $\mathrm{AqEh}$ $3.25 \pm 0.95 \mathrm{mgQE} / \mathrm{g}$. A previous study by Nepote et al. [28] also suggested that methanol solvent is ideal for the extraction of various phenolic components. In another study by Ben Mohamed Maoulainine et al. [29] revealed that methanolic extract of the Euphorbia helioscopia possesses a high concentration of TPC and TFC as compared to the TPC and TFC in ethanolic extract.

Since it is speculated that calorimetric assays may not be able to give a complete picture of the quality and quantity of different flavonoid and phenolic components in any extract [30], we underwent HPLC technique to validate the existence of phenolic and flavonoid components in the extracts (Table 2; Fig. 4). It was observed that three phenolic acids gallic acid, caffeic acid, and chlorogenic acid, and all the three flavonoid constituents were commonly found in all the three extracts. Among the phenolic contents, chlorogenic acid was found 


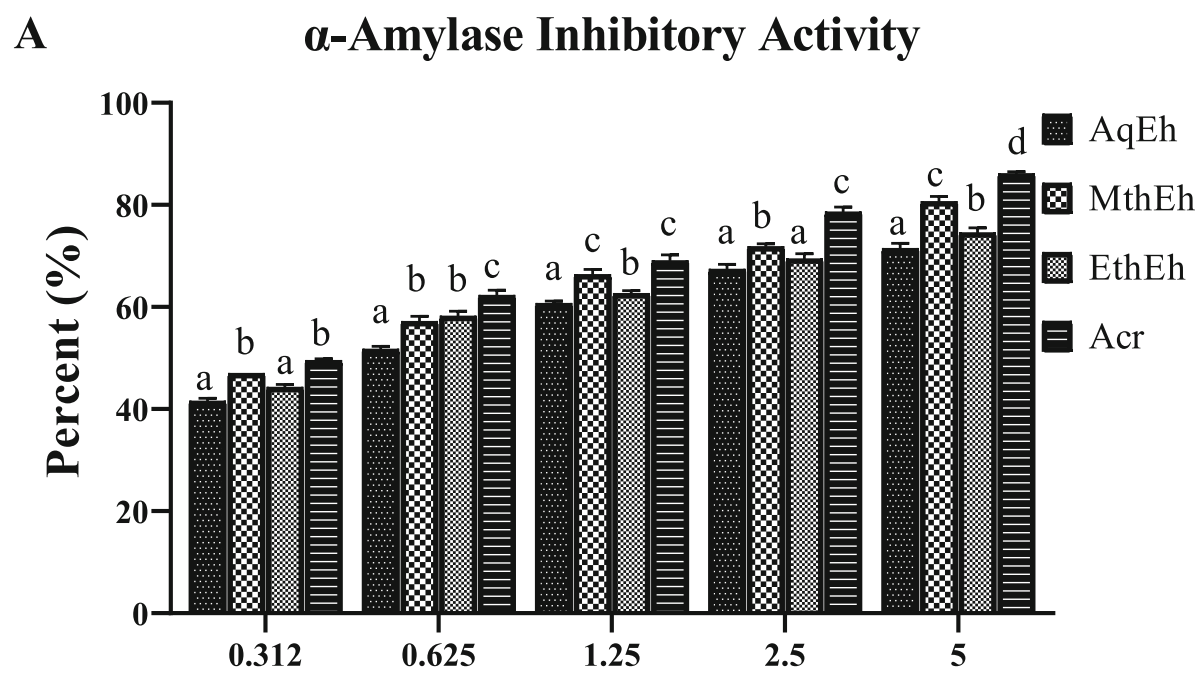

\section{B $\quad \alpha$-Amylase Inhibitory Activity}

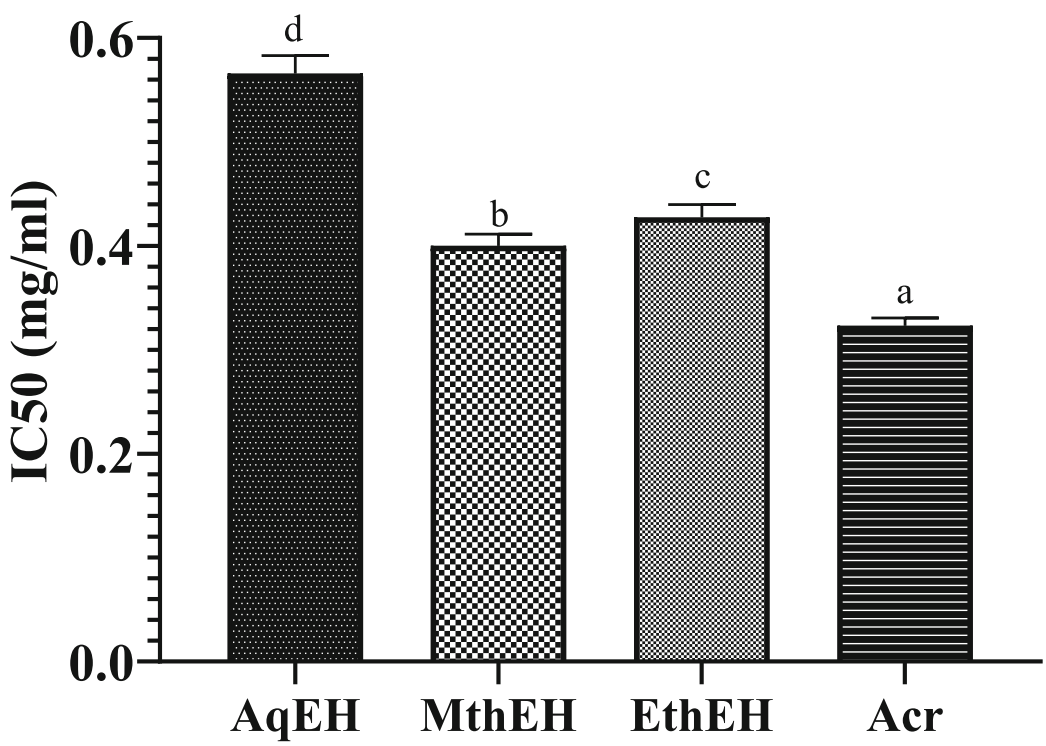

Fig. 2 a a Amylase inhibitory activity of five different concentrations of different extracts of Euphorbia helioscopia. $\mathbf{b} I_{50}$ value of a Amylase inhibitory activity of different extracts of Euphorbia helioscopia. Results are Mean \pm Standard Deviation of three replicates of each group. Different lowercase letters $\left({ }^{a}\right.$ to $\left.{ }^{d}\right)$ above the bars indicate a significant difference between groups $(P \leq 0.05)$. MthEh: methanolic extract of Euphorbia helioscopia; EthEh: Ethanolic extract of Euphorbia helioscopia; AqEh: Aqueous extract of Euphorbia helioscopia; Acr: Acarbose (standard drug)

maximum in MtEh and AqEh, while gallic acid was found maximum in EthEh. Several pieces of research have demonstrated that phenolic compounds possess effective antioxidant power and radical scavenging potential [31]. The antioxidant power of phenolic contents is primarily because of their redox activities, due to which they play a role as reducing mediators, proton donors, and oxygen quencher [32]. In the present study, $\mathrm{DPPH}^{\bullet}$, FRAP and ABTS assays were used to evaluate the antioxidant potential of the plant extracts. Data showed a significant antioxidant effect of all plant extracts. FRAP results showed that the MthEh possessed the highest antioxidant ability in comparison with EthEh and AqEh. Likewise, the ABTS result also verified that of MthEh contained the highest antioxidant ability among all extracts. The free radicals scavenging ability of all extracts was also assessed through $\mathrm{DPPH}^{\bullet}$ in-vitro assay that substantiated the previous findings. Various studies confirm the close association of phenolic and flavonoids with antioxidant activity [33]. 


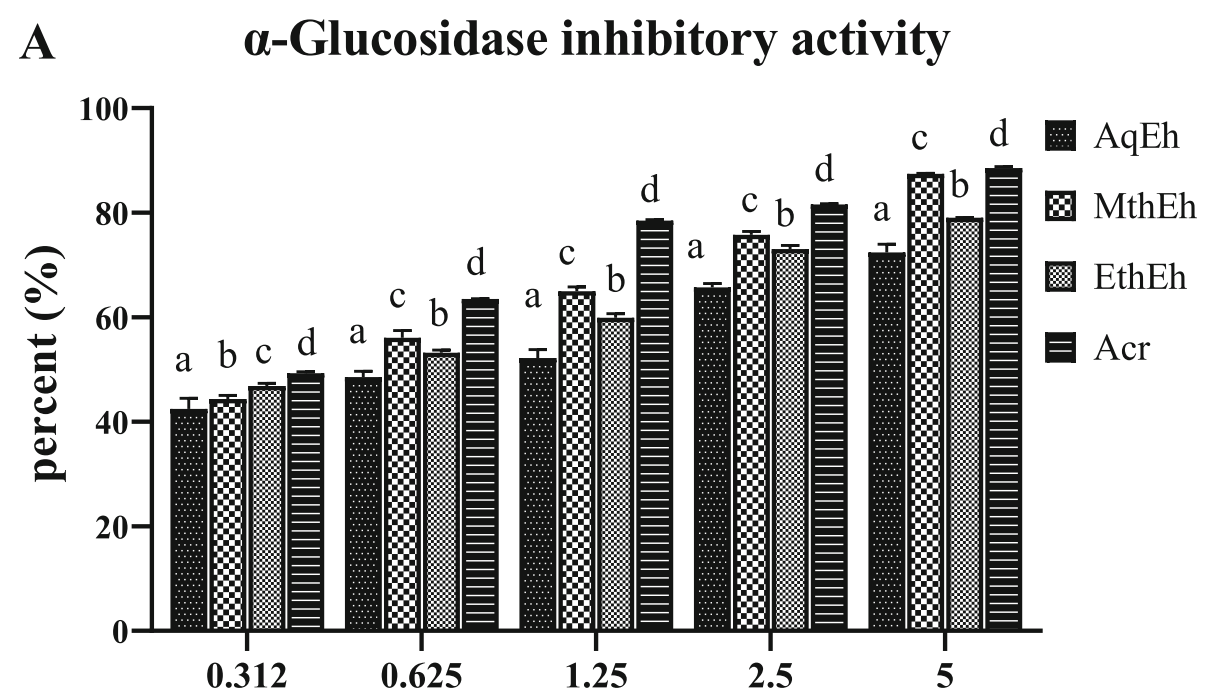

\section{B $\alpha$-Glucosidase inhibitory activity}

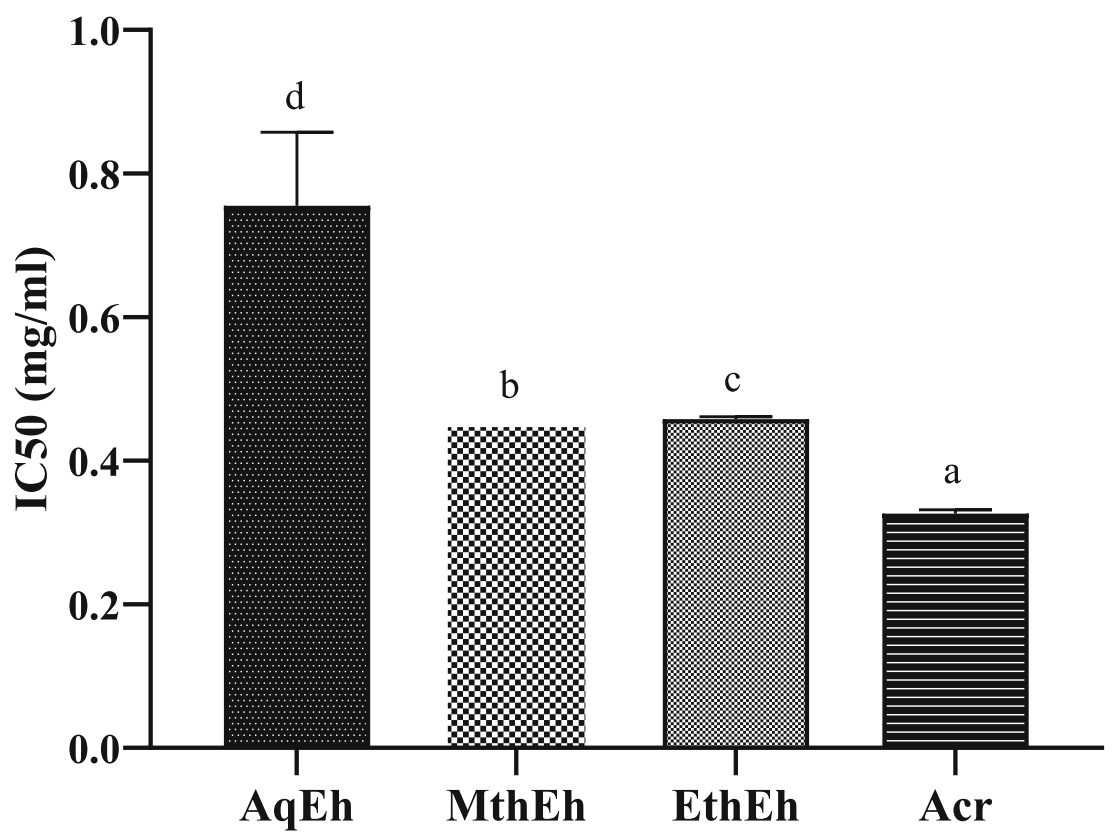

Fig. 3 a a glucosidase inhibitory activity of five different concentrations of different extracts of Euphorbia helioscopia. $\mathbf{b} \mid C_{50}$ value of a Glucosidase inhibitory activity of different extracts of Euphorbia helioscopia. Results are Mean \pm Standard Deviation of three replicates of each group. Different lowercase letters ( ${ }^{a}$ to ${ }^{d}$ ) above the bars indicate a significant difference between groups ( $\left.P \leq 0.05\right)$. MthEh: methanolic extract of Euphorbia helioscopia; EthEh: Ethanolic extract of Euphorbia helioscopia; AqEh: Aqueous extract of Euphorbia helioscopia; Acr: Acarbose (standard drug)

The current study also suggested a close relationship of total flavonoid and phenolic components with the $\mathrm{DPPH}^{\bullet}$, FRAP, and ABTS results. Table. 4 shows a $99 \%$ correlation among FRAP and TPC $(r=0.993)$ and a95\% correlation among ABTS results and TPC $(r=0.953)$. This study also shows that the increased $\mathrm{DPPH}^{\bullet}$ scavenging ability of MthEh is also due to the increased TPC and TFC of MthEh. That's why a strong negative correlation of $98 \%$ was seen among $\mathrm{TPC}$ and $\mathrm{IC}_{50}$ concentration of $\mathrm{DPPH}^{\bullet}$ radical scavenging activity, suggesting that an increase in the TPC will increase the $\mathrm{DPPH}^{\bullet}$ scavenging ability $(r=-0.989)$. A similar relation of TFC was also seen with $\mathrm{DPPH}^{\bullet}$ scavenging ability, FRAP and ABTS radical scavenging ability of different extract of Euphorbia helioscopia (Table. 4). Phenolic acids and flavonoid contents, in general, contribute towards an 
Table 4 Pearson's correlation coefficients of phytochemicals in E. H with different antioxidant and antidiabetic parameters

\begin{tabular}{|c|c|c|c|c|c|c|c|}
\hline & \multicolumn{2}{|c|}{ Phytochemicals } & \multicolumn{3}{|c|}{ Antioxidant activity } & \multicolumn{2}{|l|}{ Antidiabetic activity } \\
\hline & $\overline{T P C}$ & TFC & FRAP & TEAC & $\begin{array}{l}\mathrm{IC}_{50} \text { value } \\
\text { of DPPH }\end{array}$ & $\begin{array}{l}\mathrm{IC}_{50} \text { value of a-amylase } \\
\text { inhibitory activity }\end{array}$ & $\begin{array}{l}\mathrm{IC}_{50} \text { value of a-glucosidase } \\
\text { inhibitory activity }\end{array}$ \\
\hline \multicolumn{8}{|l|}{ Phytochemicals } \\
\hline TPC & 1 & & $0.993^{* *}$ & $0.953^{* *}$ & $-0.989^{* *}$ & $-0.999^{* *}$ & $-0.848^{* *}$ \\
\hline TFC & - & 1 & $0.972^{* *}$ & $0.982^{* *}$ & $-0.9995^{* *}$ & $-0.997^{* *}$ & $-0.904^{* *}$ \\
\hline \multicolumn{8}{|l|}{ Antioxidant activity } \\
\hline FRAP & $0.993^{* *}$ & $0.972^{* *}$ & 1 & - & - & $-0.98^{* *}$ & $-0.778^{* *}$ \\
\hline TEAC & $0.953^{* *}$ & $0.982^{* *}$ & - & 1 & - & $-0.992^{* *}$ & $-0.969^{* *}$ \\
\hline $\mathrm{IC}_{50}$ value of DPPH & $-0.989^{* *}$ & $-0.9995^{* *}$ & - & - & 1 & $0.996^{* *}$ & $0.917^{* *}$ \\
\hline \multicolumn{8}{|l|}{ Antidiabetic activity } \\
\hline $\begin{array}{l}\mathrm{IC}_{50} \text { value of } \alpha \text {-amylase in- } \\
\text { hibitory activity }\end{array}$ & $-0.999^{* *}$ & $-0.997^{* *}$ & $-\overline{0.98^{* *}}$ & -0.992 & $0.996^{* *}$ & 1 & - \\
\hline $\begin{array}{l}\mathrm{IC}_{50} \text { value of a-glucosidase } \\
\text { inhibitory activity }\end{array}$ & $-0.848^{* *}$ & $-0.904^{* *}$ & $-\overline{0.778^{* *}}$ & $-0.969^{* *}$ & $0.917^{* *}$ & - & 1 \\
\hline
\end{tabular}

** Correlation is significant at $(p \leq 0.01)$

important class of bioactive constituents, which play a key role as antioxidants [34], and act by neutralizing the hydroxyl ions [35], superoxide anion radicals [36], and lipid proxy radicals [37]. A previous study by Chandra et al. [38] described that total phenolic content contributes about 61 and $75 \%$ to the antioxidant properties in the tower garden and field-grown crops, respectively. They also described the correlation among the total flavonoids content and antioxidant activity that flavonoids contribute 32 and $30 \%$ in the tower garden and field grown crops. The methanol extract of the leaves of $\mathrm{Eu}$ phorbia helioscopia can increase the antioxidant enzymes, including catalase, superoxide dismutase, and glutathione [39]. The study of Ben Mohamed Maoulainine et al. [29] also explained that the methanolic extract that showed higher TPC and TFC values showed maximum $\mathrm{DPPH}^{\bullet}$ radical scavenging activity in terms of $\mathrm{IC}_{50}$ value as compared to the ethanolic extract, which justifies the results of our study.

By virtue of antioxidant and anti-inflammatory properties, phenolic contents in plants prevent the oxidation process and protect cell injury to avoid the danger of degenerative diseases, including diabetes mellitus type II [40-42]. The $\alpha$ amylase, produced from the salivary glands and pancreas, plays a main role in the digestion of carbohydrates by breaking the alpha bonds of polysaccharides. Likewise, $\alpha$ glucosidase is another significant enzyme present in the intestinal lumen and membrane brush border, help to digest the carbohydrates by converting starch and oligosaccharide into monosaccharides [43]. Thus, both these enzymes work to increase postprandial blood glucose level, which is strongly associated with micro and macrovascular complications in diabetes mellitus. Inhibitors of these enzymes are anticipated to suppress these enzymes' activity, delaying starch conversion into disaccharides and monosaccharides, which would ultimately decrease the glucose absorption and drop the postprandial glucose levels [44]. Drugs like acarbose and miglitol are competitive inhibitors of $\alpha$ glucosidases and $\alpha$ amylase that work to delay carbohydrates' digestion. These synthetic drugs may still result in diarrhea, softening of feces, and abdominal discomfort [45]. Through in-vitro analysis of $\alpha$ amylase and $\alpha$ glucosidase inhibitory activity, we aimed to evaluate the natural inhibitors of these enzymes present in different extracts of Euphorbia helioscopia. Our results showed that MthEh possessed the maximum inhibitory ability of $\alpha$ amylase enzyme activity, having the lowest $\mathrm{IC}_{50} \mathrm{com}-$ pared to EthEh and AqEh. Similarly, the results indicated that MthEh possessed the maximum $\alpha$ glucosidase inhibitory activity and the lowest $\mathrm{IC}_{50}$ value among all extracts. Many researches described the antidiabetic activities of the plants belong to Euphorbiaceae family such as Euphorbia hirta was tested for its antidiabetic potential in streptozotocin induced diabetic mice and the results showed that the plant inhibited the activity of $\alpha$ amylase and significantly reduced blood glucose level in hyperglycemic mice [46]. Tuhin et al. [47] evaluated Euphorbia hirta wound healing property in the diabetic rats and the plant also lowered the blood glucose level.

The correlation of TFC and TPC with the antidiabetic potential of the plant extracts has shown that greater the TFC and TPC, greater will be the ability of the extracts to inhibit $\alpha$ amylase and $\alpha$ glucosidase enzyme activities (Table. 4). The study also indicated that the plant's aqueous extract possessed the lowest concentration of flavonoids with the maximum $\alpha$ amylase and $\alpha$ glucosidase inhibitory activity. The mechanisms of action that play a role in the inhibition of these enzymes by the plant ingredients are not known properly. Still, a few studies 


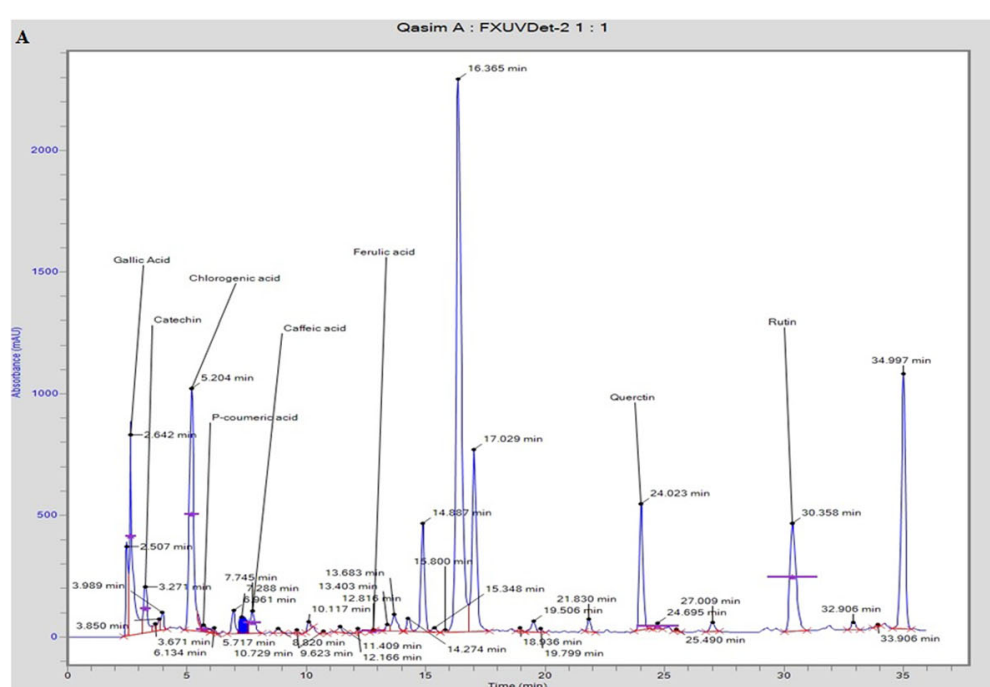

B

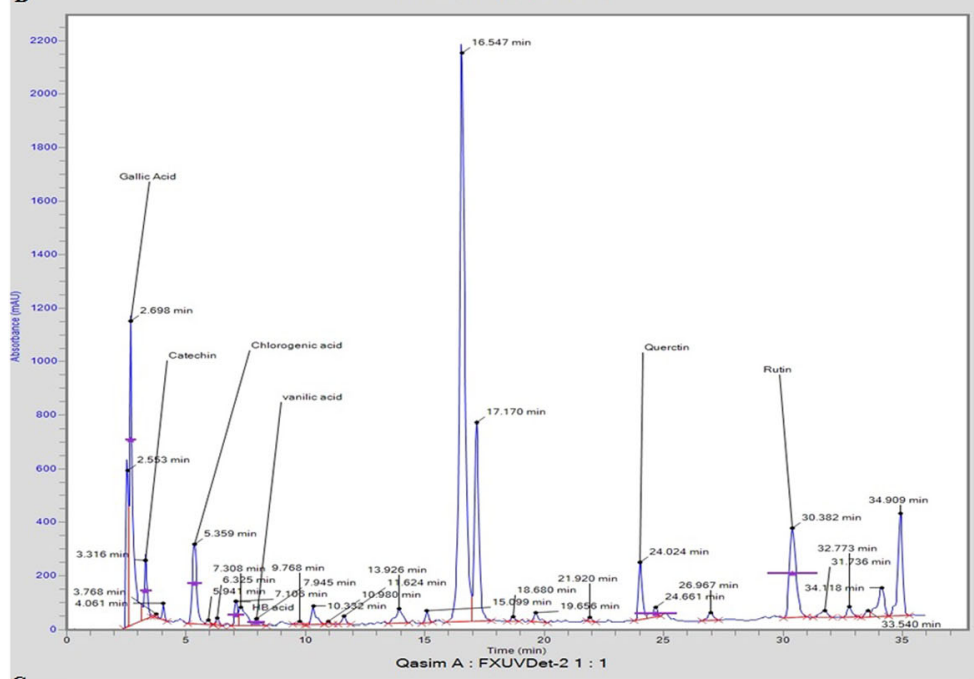

C

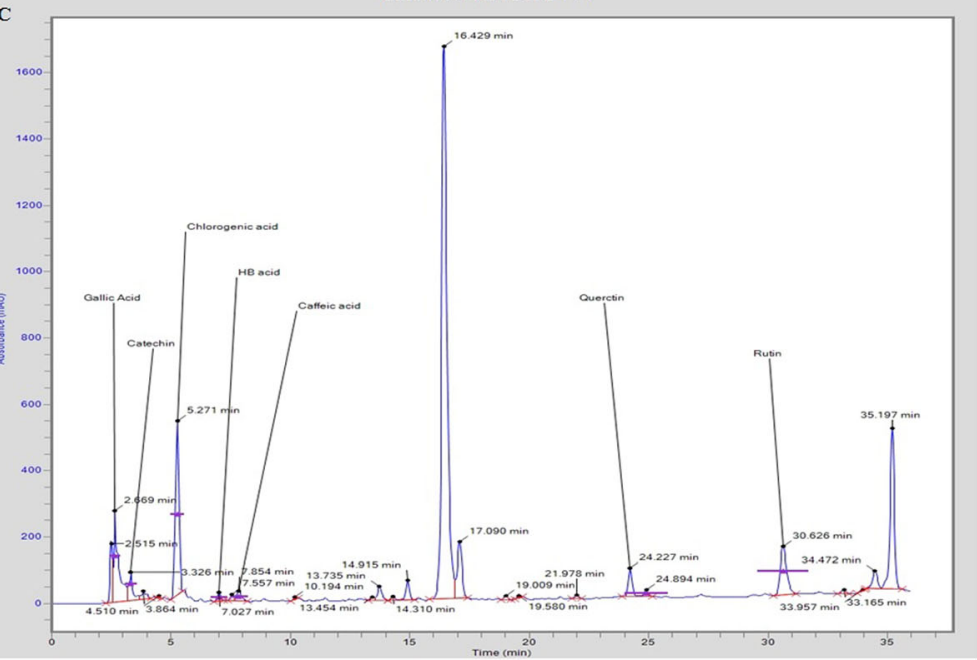

Fig. 4 HPLC chromatograms of different extracts of Euphorbia helioscopia. a HPLC Chromatogram of methanolic extract of Euphorbia helioscopia. b HPLC Chromatogram of ethanolic extract of Euphorbia helioscopia. c HPLC Chromatogram of aqueous extract of Euphorbia helioscopia 
suggest that flavonoids might induce some conformational changes in these enzymes' structures, hence blocking their activity. The findings of earlier research by Narkhede et al. [44] presented that gallic acid may inhibit the $\alpha$ amylase enzyme, which coincides with our results. However, $\alpha$ amylase and $\alpha$ glucosidase inhibitory activity of our study show contrary results in which MthEh showed more antidiabetic activity than EthEh. This difference might be due to other plant ingredients like tannins, which also play an important role in inhibiting $\alpha$ amylase activity [44].

\section{Conclusions}

In conclusion, our study revealed that methanolic extract of the Euphorbia helioscopia has the highest antioxidant capability among other extracts since it contains the highest FRAP and scavenging ability towards the radicals ABTS and $\mathrm{DPPH}^{\bullet}$, of high TFC and TPC values. In terms of $\alpha$ amylase and $\alpha$ glucosidase inhibition, methanolic extract shows maximum antidiabetic activity. These extracts must be further analyzed and characterized for future research to identify and synthesize antidiabetic drugs by searching the mode of action of different constituents towards the management of diabetes.

\section{Abbreviations}

FRAP: Ferric Reducing Antioxidant Potential; ABTS: (2,2'-azino-bis (3ethylbenzothiazoline-6-sulfonic acid)); $\mathrm{DPPH}^{\bullet}$ : (1,1-Diphenyl-2-picrylhydrazyl); MthEh: methanolic extract of Euphorbia helioscopia; EthEh: Ethanolic extract of Euphorbia helioscopia; AqEh: Aqueous extract of Euphorbia helioscopia; DW: Dry Weight; Acr: Acarbose; TFC: Total flavonoid contents; TPC: Total phenolic contents

\section{Acknowledgements}

Not Applicable.

\section{Authors' contributions}

IM, HA and MNF conceptualized the study, IM, HM and AS performed the in vitro antioxidant and antidiabetic analysis. GH and MUI helped IM in the plant extraction and phytochemical analysis. IM, HA and HM participated in the technical writing of the manuscript. MI, MUS and Al conducted a critical review and editing of the manuscript. All authors read and approved the final manuscript.

\section{Funding}

Not applicable.

\section{Availability of data and materials}

The datasets used and/or analyzed during the current study are available from the corresponding author on reasonable request.

\section{Ethics approval and consent to participate}

The study has been approved by the Directorate of Advance studies, Government College University, Faisalabad, Pakistan, GCUF/DAS/19/2469.

\section{Consent for publication}

All authors give their consent for this manuscript to be published.

\section{Competing interests}

All the authors declare that they have no conflict of interest.

\section{Author details}

${ }^{1}$ Department of Physiology, Faculty of Life Sciences, Government College University, Faisalabad, Pakistan. ${ }^{2}$ Institute of Physiology and Pharmacology,
University of Agriculture, Faisalabad, Pakistan. ${ }^{3}$ Department of Food Science, Faculty of Life Sciences, Government College University, Faisalabad, Pakistan. ${ }^{4}$ Department of Zoology, Wildlife and Fisheries, University of Agriculture, Faisalabad, Pakistan. ${ }^{5}$ Biomedical Research Centre, Qatar University, Doha, Qatar.

Received: 9 May 2020 Accepted: 2 February 2021

Published online: 12 February 2021

\section{References}

1. Kasote DM, Katyare SS, Hegde MV, Bae H. Significance of antioxidant potential of plants and its relevance to therapeutic applications. Int J Biol Sci. 2015;11(8):982.

2. Nisar J, Mustafa I, Anwar H, Sohail MU, Hussain G, Ullah MI, Faisal MN, Bukhari SA, Basit A. Shiitake culinary-medicinal mushroom, Lentinusedodes (Agaricomycetes): a species with antioxidant, immunomodulatory, and hepatoprotective activities in hypercholesterolemic rats. Int J Med Mushrooms. 2017:19(11):981-90.

3. Rusu ME, Fizesan I, Pop A, Mocan A, Gheldiu AM, Babota M, Vodnar DC, Jurj A, Berindan-Neagoe I, Vlase L, Popa DS. Walnut (Juglans regia L.) Septum: Assessment of Bioactive Molecules and In Vitro Biological Effects. Molecules. 2020;25(9):2187.

4. Gali-Muhtasib H, Hmadi R, Kareh M, Tohme R, Darwiche N. Cell death mechanisms of plant-derived anticancer drugs: beyond apoptosis. Apoptosis. 2015 Dec 1;20(12):1531-62

5. Ksouri R, Ksouri WM, Jallali I, Debez A, Magné C, Hiroko I, Abdelly C. Medicinal halophytes: potent source of health promoting biomolecules with medical, nutraceutical and food applications. Crit Rev Biotechnol. 2012; 32(4):289-326

6. Pan SY, Zhou SF, Gao SH, Yu ZL, Zhang SF, Tang MK, Sun JN, Ma DL, Han YF, Fong WF, Ko KM. New perspectives on how to discover drugs from herbal medicines: CAM's outstanding contribution to modern therapeutics. Evid Based Complement Alternat Med. 2013;2013 https://doi.org/10.1155/2 013/627375

7. Li S, Tan HY, Wang N, Zhang ZJ, Lao L, Wong CW, Feng Y. The role of oxidative stress and antioxidants in liver diseases. Int J Mol. 2015;16(11): 26087-124.

8. Anwar $\mathrm{H}$, Hussain $\mathrm{G}$, Mustafa I. Antioxidants from natural sources. Antioxidants Foods Applications. 2018:8:3-28. https://doi.org/10.5772/ intechopen.75961.

9. Niedzielska E, Smaga I, Gawlik M, Moniczewski A, Stankowicz P, Pera J, Filip M. Oxidative stress in neurodegenerative diseases. Mol Neurobiol. 2016; 53(6):4094-125.

10. Zephy D, Ahmad J. Type 2 diabetes mellitus: role of melatonin and oxidative stress. Diabetes MetabSyndr: Clinical Research \& Reviews. 2015 9(2):127-31.

11. Patten DA, Germain $M$, Kelly MA, Slack RS. Reactive oxygen species: stuck in the middle of neurodegeneration. J Alzheimers Dis. 2010 Jun 3;20(s2):S357-67.

12. Pham-Huy LA, He H, Pham-Huy C. Free radicals, antioxidants in disease and health. Int J Biomed Sci. 2008:4(2):89,

13. Nowotny K, Jung T, Höhn A, Weber D, Grune T. Advanced glycation end products and oxidative stress in type 2 diabetes mellitus. Biomolecules. 2015;5(1):194-222

14. Maritim AC, Sanders A, Watkins lii JB. Diabetes, oxidative stress, and antioxidants: a review. J Biochem Mol Toxic. 2003;17(1):24-38.

15. Zhang W, Guo YW. Chemical studies on the constituents of the chinese medicinal herb Euphorbia helioscopiaL. Chem Pharm Bull. 2006;54(7): 1037-9.

16. Park KH, Koh DS, Lee SH, Jung IM, Kim KH, Lee CH, Kim KH, Lim YH. Antiallergic and anti-asthmatic activity of helioscopinin-a, a polyphenol compound, isolated from Euphorbia helioscopia. J Microbiol Biotechnol. 2001;11(1):138-42.

17. Barla A, Bìrman H, KÜLTÜR Ş, Öksüz S. Secondary metabolites from Euphorbia helioscopia and their vasodepressor activity. Turk J Chem. 2006; 30(3):325-32.

18. Uzair M, Loothar BA, Choudhary BA. Biological screening of Euphorbia helioscopia L. Pak J Pharm Sci 2009:22(2):184-6.

19. Mu SZ, Shang S, Yan C, Yang FM, Hao XJ. Study on chemical constituents of Euphorbia helioscopia and their antitumor activities. Zhong Yao Cai. 2013; 36(7):1092-6. 
20. Saleem U, Ahmad B, Ahmad M, Hussain K, Bukhari NI. Anti-nociceptive, antiinflammatory and anti-pyretic activities of latex and leaves methanol extract of Euphorbia helioscopia. Asian Pac J Trop Dis. 2015;5(4):322-8.

21. Webster GL. Classification of the Euphorbiaceae. Ann Missouri Bot. 1994;1:3-2.

22. Singh KL, Bag GC. Phytochemical analysis and determination of total phenolics content in water extracts of three species of Hedychium. Int J PharmTech Res. 2013;5(4):1516-21.

23. Kumar JA, Sharma P, Sikarwar MS. Evaluation of anti-inflammatory and antipyretic activity of total alcoholic extract of Cro-ton sparsiflorus and its fractions. J Pharm Res. 2010;3(5):1149-51.

24. Hussain Al, Rathore HA, Sattar MZ, Chatha SA. Ud din Ahmad F, Ahmad a, Johns EJ. Phenolic profile and antioxidant activity of various extracts from Citrullus colocynthis (L.) from the Pakistani flora. Ind Crop Prod. 2013;45: 416-22.

25. Dudonne S, Vitrac X, Coutiere P, Woillez M, Mérillon JM. Comparative study of antioxidant properties and total phenolic content of 30 plant extracts of industrial interest using DPPH, ABTS, FRAP, SOD, and ORAC assays. J Agric Food Chem. 2009;57(5):1768-74.

26. Adebiyi OE, Olayemi FO, Ning-Hua T, Guang-Zhi Z. In vitro antioxidant activity, total phenolic and flavonoid contents of ethanol extract of stem and leaf of Grewiacarpinifolia. Beni-Suef Univ J Basic Appl Sci. 2017:6(1):10-4.

27. Chokki M, Cudălbeanu M, Zongo C, Dah-Nouvlessounon D, Ghinea IO, Furdui B, Raclea R, Savadogo A, Baba-Moussa L, Avamescu SM, Dinica RM. Exploring antioxidant and enzymes (A-amylase and B-Glucosidase) inhibitory activity of Morinda lucida and Momordica charantia leaves from Benin. Foods. 2020;9(4):434.

28. Nepote V, Grosso NR, Guzmán CA. Optimization of extraction of phenolic antioxidants from peanut skins. J Sci Food Agric. 2005;85(1):33-8.

29. Ben Mohamed Maoulainine L, Jelassi A, Hassen I, Ould Mohamed Salem OuldBoukhari A. Antioxidant proprieties of methanolic and ethanolic extracts of Euphorbia helioscopia, (L.) aerial parts. Int Food Res J. 2012;19(3): 1125-1130.

30. Elazzouzi H, Zekri N, Zair T, Alaoui El Belghiti M. Total phenolic and flavonoid contents of Anacyclus pyrethrum Link plant extracts and their Antioxidant activity. Karbala Int J Mod Sci. 2019;5(4):10.

31. Sugihara N, Arakawa T, Ohnishi M, Furuno K. Anti-and pro-oxidative effects of flavonoids on metal-induced lipid hydroperoxide-dependent lipid peroxidation in cultured hepatocytes loaded with a linolenic acid. Free Radic Biol Med. 1999;27(11-12):1313-23.

32. Rice-Evans CA, Miller NJ, Paganga G. Structure-antioxidant activity relationships of flavonoids and phenolic acids. Free Radic Biol Med. 1996; 20(7):933-56.

33. Khang DT, Dung TN, Elzaawely AA, Xuan TD. Phenolic profiles and antioxidant activity of germinated legumes. Foods. 2016;5(2):27.

34. Adesegun SA, Fajana A, Orabueze Cl, Coker HA. Evaluation of antioxidant properties of Phaulopsisfascisepala CB Cl. (Acanthaceae). Evid Based Complement Alternat Med. 2009;6(2):227-31.

35. Husain SR, Cillard J, Cillard P. Hydroxyl radical scavenging activity of flavonoids. Phytochemistry. 1987;26(9):2489-91.

36. Afanas' ev IB, Dcrozhko Al, Brodskii AV, Kostyuk VA, Potapovitch Al. Chelating and free radical scavenging mechanisms of inhibitory action of rutin and quercetin in lipid peroxidation. BiochemPharmacol. 1989;38(11): 1763-1769.

37. Torel J, Cillard J, Cillard P. Antioxidant activity of flavonoids and reactivity with peroxy radical. Phytochemistry. 1986;25(2):383-5.

38. Chandra S, Khan S, Avula B, Lata H, Yang MH, ElSohly MA, Khan IA. Assessment of total phenolic and flavonoid content, antioxidant properties, and yield of aeroponically and conventionally grown leafy vegetables and fruit crops: a comparative study. Evid Based Complement Alternat Med. 2014;2014 https://doi.org/10.1155/2014/253875.

39. Saleem U, Ahmad B, Ahmad M, Hussain K, Bukhari NI. Investigation of in vivo antioxidant activity of Euphorbia helioscopia latex and leaves methanol extract: a target against oxidative stress induced toxicity. Asian Pac J Trop Med. 2014;7:S369-75.

40. Xu JG, Tian CR, Hu QP, Luo JY, Wang XD, Tian XD. Dynamic changes in phenolic compounds and antioxidant activity in oats (Avena nuda L.) during steeping and germination. J Agric Food Chem. 2009;57(21):10392-8.

41. Nderitu AM, Dykes L, Awika JM, Minnaar A, Duodu KG. Phenolic composition and inhibitory effect against oxidative DNA damage of cooked cowpeas as affected by simulated in vitro gastrointestinal digestion. Food Chem. 2013;141(3):1763-71.
42. Afshin A, Micha R, Khatibzadeh S, Mozaffarian D. Consumption of nuts and legumes and risk of incident ischemic heart disease, stroke, and diabetes: a systematic review and meta-analysis. Am J Clin Nutr. 2014;100(1):278-88.

43. Puls W, Keup U, Krause HP, Thomas G, Hoffmeister F. Glucosidase inhibition. A new approach to the treatment of diabetes, obesity, and hyper lipoproteinaemia. Pascal and Francis Bibliographic Databases. 1977;64(10): $536-7$.

44. Narkhede MB, Ajimire PV, Wagh AE, Mohan M, Shivashanmugam AT. In vitro antidiabetic activity of Caesalpinadigyna (R.) methanol root extract. Asian J Plant Sci Res. 2011;1(2):101-6.

45. Abraham BP, Sellin JH. Drug-induced, factitious, \& idiopathic diarrhoea. Best Pract Res Clin Gastroenterol. 2012;26(5):633-48.

46. Tran $\mathrm{N}$, Tran M, Truong H, Le L. Spray-drying microencapsulation of high concentration of bioactive compounds fragments from Euphorbia hirta L. extract and their effect on diabetes mellitus. Foods. 2020;9(7):881.

47. Tuhin RH, Begum MM, Rahman MS, Karim R, Begum T, Ahmed SU, Mostofa R, Hossain A, Abdel-Daim M, Begum R. Wound healing effect of Euphorbia hirta linn.(Euphorbiaceae) in alloxan induced diabetic rats. BMC Compl Alternative Med. 2017;17(1):423.

\section{Publisher's Note}

Springer Nature remains neutral with regard to jurisdictional claims in published maps and institutional affiliations.
Ready to submit your research? Choose BMC and benefit from:

- fast, convenient online submission

- thorough peer review by experienced researchers in your field

- rapid publication on acceptance

- support for research data, including large and complex data types

- gold Open Access which fosters wider collaboration and increased citations

- maximum visibility for your research: over $100 \mathrm{M}$ website views per year

At $\mathrm{BMC}$, research is always in progress.

Learn more biomedcentral.com/submissions 